Рад примљен: 10. 1. 2014.

Рад прихваћен: 5. 5. 2014.

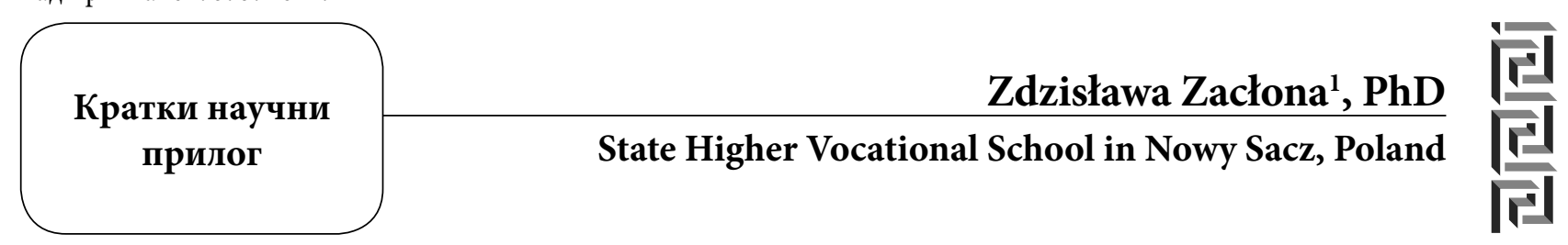

\title{
Lifelong Learning - Active Ageing at Polish Universities of Third Age
}

\begin{abstract}
The $21^{\text {st }}$ century education should be seen as a lifelong process. Lifelong learning becomes the foundation of human knowledge, their activity, ability to live in a society, but also to create yourself and your own existence.

With the growing awareness of the aging population in Europe, the issues of education and active aging have been discussed for years. The announcement by the European Parliament and the Council that year 2012 would be the European Year for Active Ageing and International Solidarity is the appreciation of potential in the hands of senior citizens and the elderly, as well as the opening up to their needs. Poland's parliamentary upper house, the Senate, had recognized senior education as important for the state and declared 2012 the Year of Universities of the Third Age. A large number of UTA students in Poland, a rich and diverse range of educational and activating activities, as well as taking initiative, reinforce the belief that the period of late maturity through an active lifestyle prevents exclusion from the community and improves the quality of life by giving it a valuable meaning.
\end{abstract}

Key words: lifelong learning, active aging, university of third age.

\section{Introduction}

Poland is nowadays following the transformation path towards a global information society. Scientific and technical progress in the information technology and telecommunications leads to new business solutions, a change in working and life style, as well as in organization of the society and its institutions. Education becomes the key component to be part of the global information society - it is the factor that determines social membership, as keeping up with the progress, being an inherent feature of

1 briw@pwsz-ns.edu.pl the society, depends on nothing else but education (Report on Social Development, 2002: 3-4). The "Poland 2000 Plus" Forecasting Committee Members say: "We agreed at a Conference on the Strategy for Poland for Years 2004-2015 on the priority of education - as a standalone goal and the factor behind social and economic changes, as well as self-fulfillment of individuals and human communities" (Banach \& Rajkiewicz, 2002: 125).

Living in a society based on knowledge and information, we experience more clearly and much more strongly the changes that result from globalization. The dynamics of modern changes and rapid 
obsolescence of knowledge confirm the legitimacy of viewing the diagnosis of the status of modern education as prepared by the authors of the report, by the International Commission on $21^{\text {st }}$ Century Education, entitled Education - Comprising a Hidden Treasure, prepared under the supervision of J. Delors for UNESCO. Considerations, cogitations, and realistic forecast of education are presented therein in the context of education as a superior social value. It is based on four pillars that the authors consider to be the same with the following educational goals: learning to know; learning to act, learning to live together; and learning to live (Education - Comprising a Hidden Treasure, 1998: 85-98). The so presented educational goals capture learning in many ways - it becomes the foundation of human knowledge, their activities, skills of living in a society, but also those to create yourself and your own existence.

In gradually growing complexity and diversity of social tensions, learning is a kind of attitude to both knowledge and life. Although this process is already started in school education, it affects the whole human existence. We learn ontogenetic development in subsequent stages of varying intensity and at a different pace. Lifelong learning includes education from the kindergarten through to late adulthood. It takes place in formal institutions, namely the educational system units, but also it includes a wide spectrum of non-formal and informal (natural) learning.

From a practical point of view, the opportunities of learning - perceived as the acquisition of new behaviors - are not restricted by age. In the UNESCO report Learn to Be (1975), an argument was formulated that those who learn are individuals, groups of people, organizations, and even the entire societies. The $21^{\text {st }}$ Century Education should be perceived as a lifelong process that aims to develop knowledge, competencies, personal and social skills, but also as self-improvement and the use of cultural heritage.

\section{Lifelong Learning in the Universities of Third Age Perspective (UTA)}

Assuming that education is the key to knowledge, and that the information society is as competitive as economy is based on knowledge, then education of people and their preparation for lifelong learning should be a strategic task of the state. This is a major challenge that brings positive consequences for both individuals and the society as a whole. Educated people understand better than those uneducated the phenomena occurring around them, have fuller access to culture, consciously protect their health, and care for a good future of their children (Poland on the way... 2002: 4).

In Europe, discussions have been held for many years about educational systems, general knowledge, and lifelong learning issues. Being aware of the aging society, it is worth appreciating education and active aging. Both the EU institutions and international organizations stress the importance of these issues. Proof of this fact can be found in both the Lisbon Strategy and in the following documents:

- Vienna Declaration, adopted in 1982 in Vienna by the First United Nations World Assembly on Ageing Societies;

- The Madrid International Action Plan on Ageing Societies, adopted by the United Nations General Assembly in 2002, and thus by Poland, as United Nations Member;

- Decision No. 1720/2006/EC, by the European Parliament and by the Council as of 15 November 2006, establishing the action plan for lifelong learning (Official Journal EU PL L.327/45 of 24 Nov. 2006);

- Resolution by the EU Council on the Renewed European Agenda on Adult Learning (2011/C Official Journal EU PL No. $327 / 01)$;

- Decision No. 940/2011/UE by the European Parliament and by the EU Council as of 
14 September 2011 on the European Year for Active Ageing and Solidarity between Generations 2012 (Official Journal EU PL L.246 / 5 dated 23 Sep. 2011).

Poland, by referring to those key EU documents, shows its commitment to taking specific actions and various initiatives in the area of lifelong learning and activation of elderly persons, and which primarily aim at preventing discrimination against people because of their age and at prevention of their social exclusion. The third age universities are now one of the most numerous senior organizations in Poland - therefore, the assumption logically imposes itself that nobody else but them could better deal with the important task of addressing the problems of how aging society operates in the world of global information technology and taking many diversified actions to combat and reduce the negative effects of social exclusion.

The importance of the elderly education cannot be overestimated. The development and dynamics of the UTA activities in Poland convince us that not only young people are favored in the domestic educational policy. Initiatives and commitment of many people in the development of and systematic, admirable work for these organizations show that there is a societal need for granting higher importance to the universities of the third age.

\section{Universities of Third Age in Poland}

The idea of establishing universities of the third age in Europe goes back to 1973 when, upon the initiative of the Social Sciences Professor Pierre Vellas at the University of Toulouse in France, the first educational institution for elderly persons was set up and called: the University of the Third Age.

The idea to create universities of the third age quickly gained many followers in other countries. The first academic year in the so-called Third Age College was inaugurated on 12 November 1975 in Warsaw and it was organized by
Professor Halina Szwarc who was co-operating with Vellas. In the years 1975-1979, the number of such universities kept growing - usually they were operating within the structures of the higher education institutions, especially in cities being academic centers. Following 1989 in Poland, a further development (which is very noticeable nowadays) of universities of the third age was recorded as a result of political system transformations. This statistical data is the best illustration for that: in 2007 there were 125 universities of the third age in Poland, in 2008 - 187, and in year 2010 - as many as 248. Compliant with the quantitative data, as collected by the Polish Federation of Associations of the Universities of the Third Age, there are $410 \mathrm{UTA}^{2}$ currently operating in our country.

On the basis of the presented quantitative data, one can conclude that the development dynamics of the universities for seniors in Poland is worth emphasizing. The development of today's adult education is encouraged by both the needs and the changes in the consciousness of people, especially in their attitude to educational opportunities. "Today, people commonly believed (...) that it is worth learning and you need to learn (...). They found out that education is a value and that it is a reliable way to gain personal and social significance, and that further education is the most effective way to invest in yourself" (Alexander, 1996, p. 31).

The universities of the third age operate in Poland in various organizational and legal forms, and this diversification is conditioned by many factors, such as: the scope of activities, proximity to scientific research centers, human resources potential, financial capacities, or accessibility of cultural institutions. Given the organizational and legal forms, there are three types of UTAs:

- acting as non-governmental organizations (mostly UTA Associations and Founda-

2 Numeric data: Polish Federation of Associations of the Universities of the Third Age; materials from the Congress of the Universities of the Third Age (19-20 March 2012). 
tions) based on the Associations Act, the Foundations Law, as well as, the Law on Public Benefit and Volunteer Work.

- operating within the structures of the higher education institutions, public and nonpublic. They are appointed by the university authorities who also determine their operating rules (these entities are structurally and financially dependent on the institution), and they are managed by proxy rector. Scientific and academic workers support UTA in its organization and by conducting classes.

- operating within the structures of local government units (e.g. at the cultural or educational centers, libraries, etc.). They are appointed by local authorities who determine their operational rules and they are managed by designated staff.

Currently in Polish conditions, the largest group of the universities of the third age operates as non-governmental organizations. The variety of organizational and legal forms, in which UTA operates, provides opportunities of participation in them to the elderly, not only of large cities and towns with academic centers, but also from smaller towns. Not without significance is the fact that within educational structure UTAs are important institutions that propose multilateral activation forms of the elderly through education.

Referring to the Report on the Diagnosis of the Universities of the Third Age in Poland, it can be concluded that the extent of the territorial impact of these organizations always goes beyond the immediate surroundings and refers to the broadly understood geographical environment. These facts indicate that there is a strong public demand for services that are offered by UTA. "The elderly want to attend UTA activities, even if it is necessary to travel a certain geographical distance“ (Lenart, 2009: 7). The reported outcomes of the survey studies reinforce the belief that the popularity of the universities of the third age is significant, but also the desire and motivation for meeting cognitive needs of the seniors in various forms of educational and social activities, which are offered by UTA, correspond to their expectations. However, in order for UTA to fulfill their organizational and substantive tasks satisfactorily and on a good enough level, they must be provided with financial means and human resources potential.

When it comes to the financial situation of Polish universities of the third age, it should be noted that their activity is carried out largely by contributions from its members, regardless of their organizational and legal form. Besides the membership fees, grants are also important as additional sources of funding ( $61 \%$ of the surveyed institutions benefit from them) and donations (some $21 \%$ of UTAs receive them). Substantial is also the fact that many of the UTAs systematically use the non-financial forms of support (e.g. provision of rooms for classes and office space) because they reduce their overall operational costs. Some $20 \%$ of the surveyed universities for the senior citizens also benefit from the budget of local government units, some other support of the university, or various projects (Lenart, 2009: 8 ). However, the financial situation of UTA leaves much to be desired and constitutes one of the major obstacles to their effective operation. Popularity of education among the elderly should ensure its availability, but in the current situation the financing of activities primarily from membership fees is by no means adequate to the needs. It seems that in this situation, it is necessary for UTA to become open for attracting external funding, especially from the projects co-financed by the European Union, but for that a professional preparation is required. This raises a need for UTA interest in all forms of support and advisory services thanks to which it would have a better chance to acquire additional funding from both the EU and non-EU sources. 


\section{Active Ageing in Polish Universities of the Third Age}

The UTA's goals in Poland refer to the idea of the first French University of Toulouse which assumed that the elderly should be enabled to acquire and extend their knowledge, so that they can be included in the lifelong learning process, aiming at the improvement of the quality of their life. We keep learning throughout our entire lives in order to strengthen the sense of social responsibility, deepen self-esteem and fullness of existence. Therefore, adult education should be seen as an action that enhances the social aspect of life (Suchodolski, 2003).

Universities of the third age are the most popular form of education of the elderly, and it should be stressed that the $50+$ generation will be an increasingly important part of Polish society in the near future. This fact confirms the validity and necessity of providing a multilateral activating offer of educational courses at UTA alone.

Those organizations aim to include seniors into the "lifelong learning" system, and thus to break the stereotypes related to elder people and improve their quality of life. This goal is accomplished by taking into account in educational programs the current issues and those relevant to modern society, such as: globalization, Europeanization, computerization, or communication. Thanks to that content the problem of exclusion and social isolation of the older generation is counteracted or reduced.

An equally important objective of the UTA is also to maintain psychophysical efficiency, as long as possible after retirement. This is done through various forms of intellectual, cognitive and physical activities. Establishment and development of healthy lifestyle attitudes as well as raising the awareness of the need for seniors to move in their everyday life fits into gerontological preventive actions and promotion of a healthy lifestyle.

Integration of the elderly environment through meetings with people who have similar problems related to age limitations is implemented through the objective to maintain interpersonal bonds. Belonging to a social group reinforces mental and improves one's physical condition. Group sporting activities performed by seniors stimulate the brain to a greater release of the happiness hormone (endorphin). The company of other people or making friends is also a significant dimension of acting in a group - often it fills the emotional gap and a sense of isolation, while being an excuse to leave the house. Being a member of the group gives a person a sense of social belonging, which is particularly important for mental health.

The rich diversity of a substantive offer of the universities of the third age in Poland is a conscious assumption of their activities. In adulthood, the aging processes gain momentum and it is important not to engage in one action only. Having a variety of interests allows for better functioning in daily life and for protecting against dementia. A possibility to develop passions, hobbies and talents through participation in group educational activities as planned by UTA enhances self-esteem, while providing a feeling of self-accomplishment and satisfaction. Joy deriving from activity is an opportunity to exercise, while overcoming the age-related burdens. Encouragement to participate in social, cultural, educational, or political life prompts seniors to engage in meaningful activities of the neighborhood or social environment. A large number of contacts with a variety of people positively affects the overall well-being of older people and is an example that the work - e.g. on a voluntary basis - allows for using the potential of the seniors, their life wisdom and longterm professional experience to develop their living environment, while recognizing the position of the elderly person in the community. Mature, already retired people, are a valuable asset for the region. Through local government and civic education, they are prepared to actively participate in life of their immediate geographical and social environments. 
An important objective of the UTA is also intergenerational integration. It is of great importance in the dimension of mutual learning from each other among people of different generations. It is in these interpersonal relations that the past, history, tradition, customs, ethical rules and values get in contact with technological progress, civilizational changes and contemporary dimension of culture.

The UTAs initiate cooperation with educational and scholastic institutions, so that students of secondary schools and college students can take vocational practices and internships. Young people (mostly students) also often conduct (under a supervision of highly qualified teachers) practical computer classes, exercises in foreign languages courses, and many other forms of joint activities with UTA students. Through such cooperation there is a cultural exchange between generations. It should also be noted that many UTAs take effective cooperation with other countries, international senior organizations or universities. In this type of cooperation, it is valuable to have an exchange of experiences and get to know a wider range of people who are familiar with the problems of seniors' learning.

Not without significance is also the fact that seniors fill their free time by participating in widely activating and multilateral activities offered by UTA. The andragogic literature indicates that there are two basic functions of UTA: educational and recreational-integrational. The first one includes tasks, such as: time management, deepening of the global and human perspective, satisfaction of cognitive needs, and integration of life experience with the newly acquired knowledge, which allows for the rational planning of your own aging and a satisfactory organization of leisure. In case of the other function, it is important to build bonds of solidarity, kindness, friendship in the family, society, nation, and between generations (Drożdż, 2009: 75-78).

It is worth noting that the activities of the universities of the third age in Poland aim to involve senior citizens in the process of lifelong ed- ucation. A multi-layer and wide range offer of activities in the leading UTAs is a good example of activation, integration and inspiration to various forms of mental, physical, social, pro-health and cultural engagement. The concern of these institutions is to ensure that the elderly have decent and good conditions of aging and to form a positive image of the $50+$ generation.

\section{Summary}

At present, the issue of seniors is gaining importance not only in Poland but also worldwide. This is because there is a rapidly growing number of elderly people in highly-developed countries. Therefore, elderly people should not only be looked at from the perspective of somatic and mental health ailments, but also in terms of recognizing their potential skills. Active aging includes a widerange of areas of social, personal or family character. Many factors, such as: education, intellectual stimulation, active lifestyle, new experiences, the ability to rest, taking care of one's health, the feeling of self-acceptance and effective activity, help strengthen confidence in elderly people that they are in good psychosocial condition and help maintain the quality of their lives in dignity. Assuming the psychogerontological scientific achievements as the basis for any consideration of senior citizens, one should appreciate the power of the social movement that flows from Polish UTAs activities. They have gained a high social recognition and they are appreciated and respected for initiating comprehensive educational activities that contribute to intergenerational integration. Their contribution to the many initiatives aiming to combat social exclusion of people on the grounds of age, and meeting the needs of the older generation, perfectly corresponds to the idea of the European Year for Active Ageing and Solidarity between Generations. 


\section{References}

- Abramowicz, W. (2002). Obywatele globalnego społeczeństwa informacyjnego [in:] Polska w drodze do globalnego społeczeństwa informacyjnego. Warsaw: UNDP.

- Aleksander, T. (1996). Społeczne uzasadnienie konieczności edukacji dorosłych. Adult Education, No. 2.

- Banach, Cz. and Rajkiewicz, A. (2002). Najpilniejsze problemy do rozwiązania w systemie edukacji w latach 2004-2015 [in:] Strategia dla Polski po wejściu do Unii Europejskiej na lata 2004-2015. Warsaw: Forecasting Committee "Poland 2000 Plus" at Polish Academy of Sciences.

- Borczyk, W., Nalepa, W., Knapik, B. and Kanpik, W. (2012). Standardy działania Uniwersytetów Trzeciego Wie$k u w$ Polsce. Nowy Sącz: Polish Federation of Associations of the Universities of the Third Age.

- Delorsa, J. (ed.) (1998). Edukacja - jest w niej ukryty skarb. Warsaw: SOP.

- Drożdż, M. (2009). Edukacyjna i rekreacyjno-kulturalna funkcja Uniwersytetów Trzeciego Wieku. In: Bulzak, A. (Ed.). Kapitał intelektualny osób aktywnych zawodowo. Formy i metody zarządzania czasem poprzez ustawiczne kształcenie dorosłych. Nowy Sącz: WSB - National-Luis University.

- Lenart, M. (2009). Raport z diagnozy uniwersytetów trzeciego wieku w Polsce. Nowy Sącz: Polish Federation of Associations of the Universities of the Third Age.

- Polska $w$ drodze do globalnego społeczeństwa informacyjnego. Raport o rozwoju społecznym. Program Narodów Zjednoczonych ds. Rozwoju (UNDP) (2002). Warsaw.

- Raport o stanie państwa, the Government Centre for Strategic Studies (2004). Warsaw.

- Schimanek, T. (2012). Europejski Rok Aktywności Osób Starszych i Solidarności Międzypokoleniowej. Warsaw: Social institutions in collaboration with the Academy for the Development of Philanthropy in Poland (as ordered by the Ministry of Foreign Affairs).

- Steuden, S. (2011). Psychologia starzenia się i starości. Warsaw: Scientific Publisher PWN.

- Suchodolski, B. (2003). Edukacja permanentna, rozdroża i nadzieje. Warsaw: TWWP.

- Faure, E. (Ed.) (1975). Uczyć się, aby być. Warsaw: Scientific Publisher PWN.

- Zacłona, Z. (2006). Radość życia czyni życie pięknym. Nowy Sącz: Sadecki University of Third Age. 


\section{др Здислава Зацлона}

\section{Виша педагошка школа у Новом Сончу, Пољска}

\section{Целоживотно учење - активно старење на пољским универзитетима трећег доба}

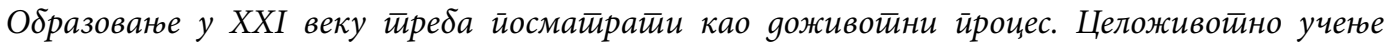

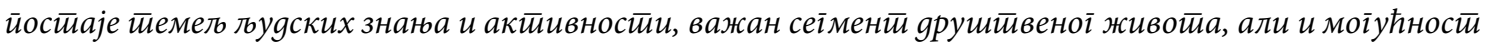

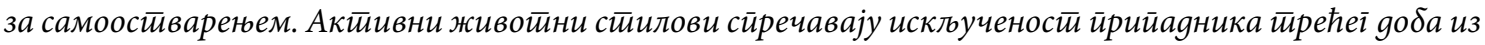

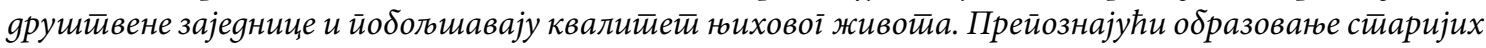

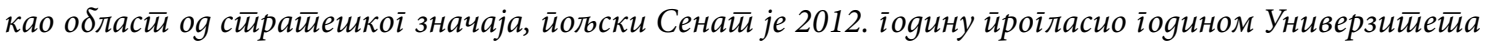

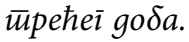

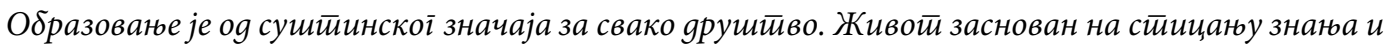
информисаностии омоіу ћава лакше уклучене у йокове ілобализаиије. У све сложенијим друшиввеним о оносима, учене оgражава сииав иррема животиу и иррема себи. Оно се оgиірава у званичним инстиитиу-

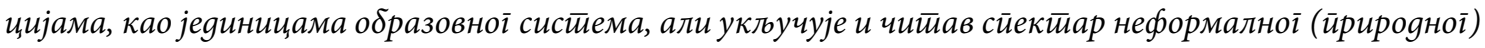

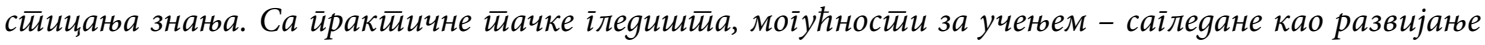

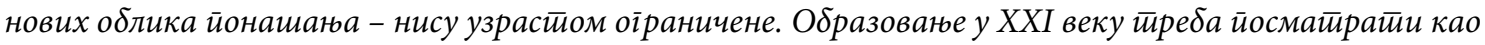

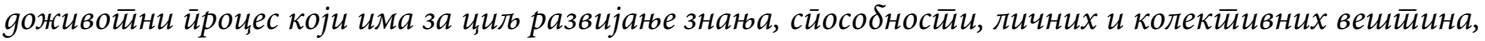
али и као вия самоуздизана, очувана личноі здрављь, иреношена куличурної наслеђа и бриїе за йоgмлайком.

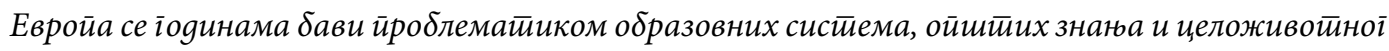

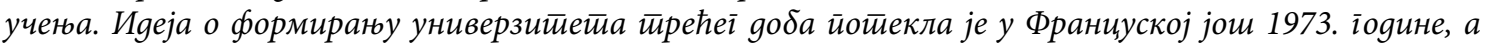

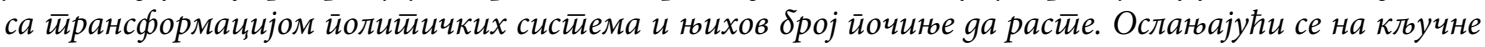

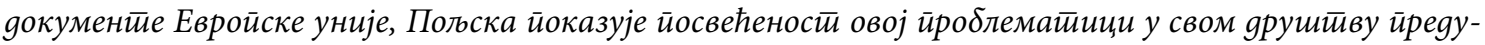

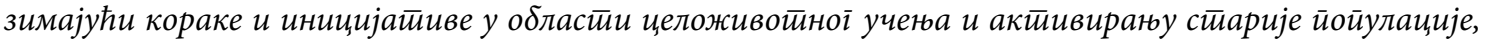

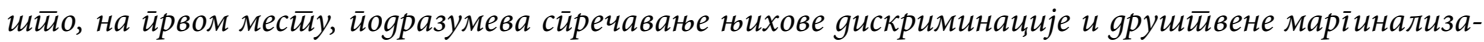

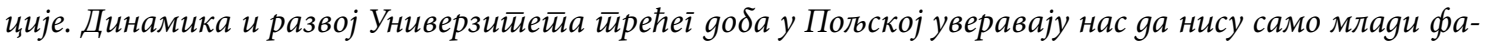
воризовани у gомаћој образовној ӣолитиици. Тако их је 2007. іолини у Полској било већ сйо gваgесети

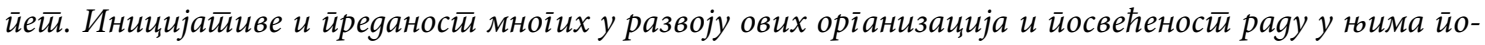

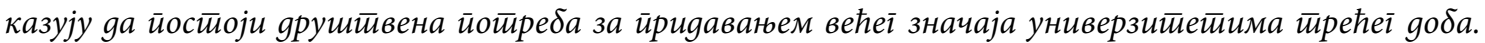
Било gа функиионишу као невлаgине орїанизације, као gео ситрукииуре званичноі система високоі

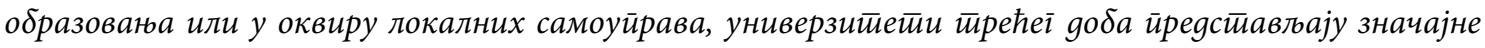

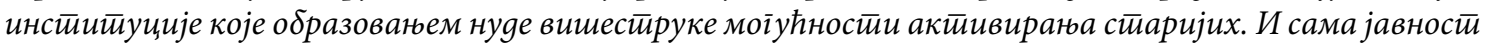

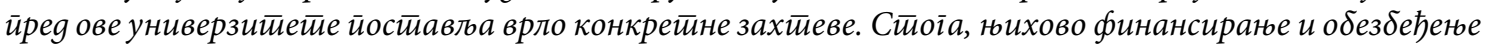
каярова йреgстиављају веома важна йийана.

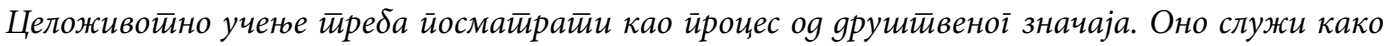

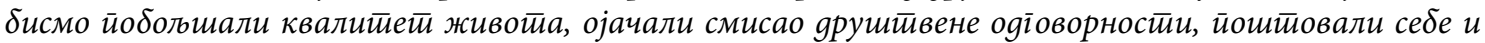

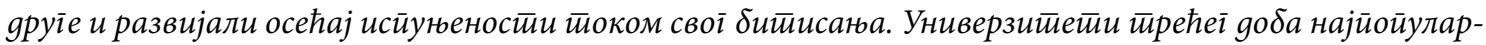

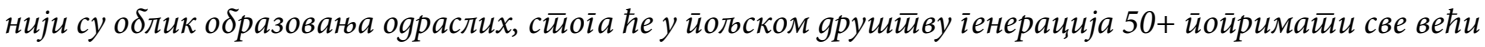

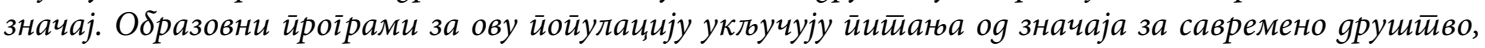

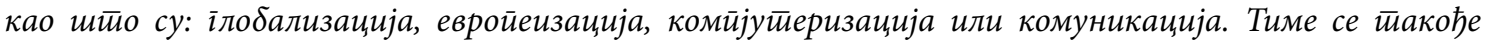
уматује изолаиија стиаријих.

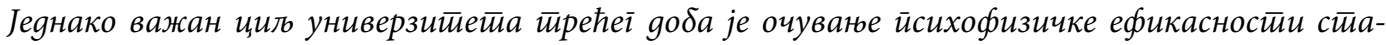

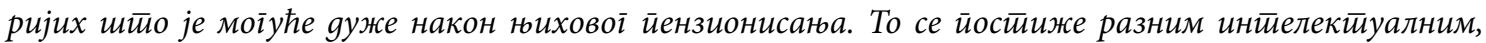

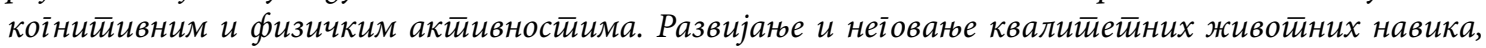




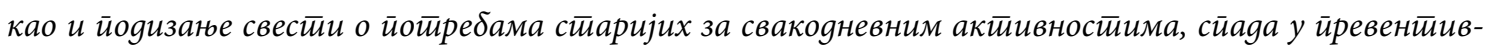

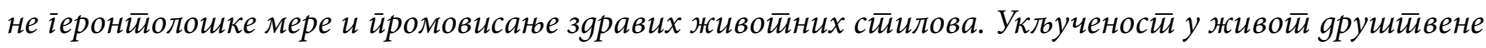

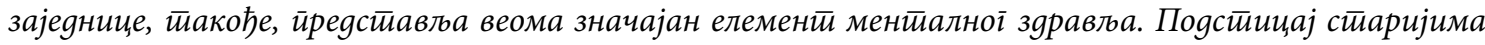

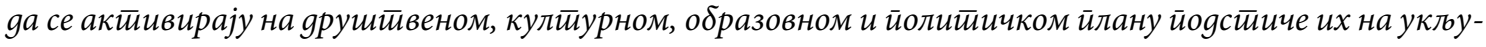
чиване у смислене актиивностии у нейосреgном окружену или широј gрушиивеној среgини. Тиме се на

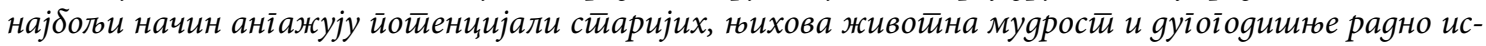

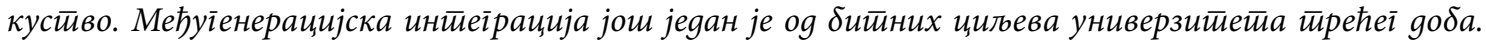

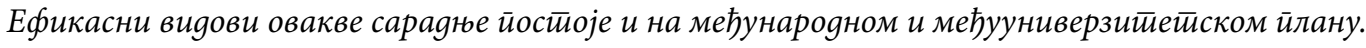

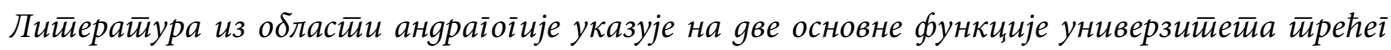

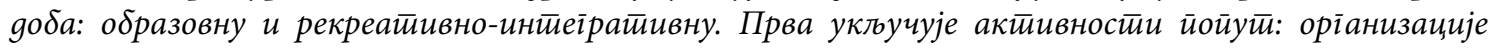

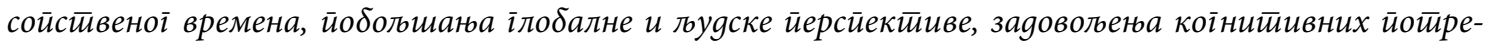

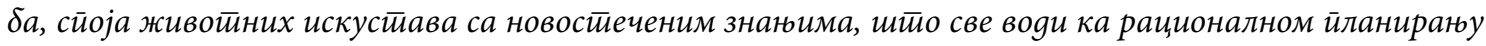

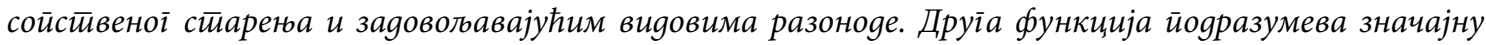

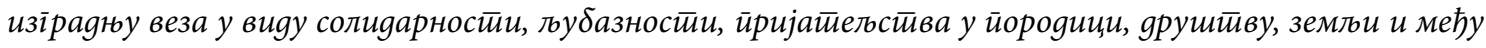
іенерацијама.

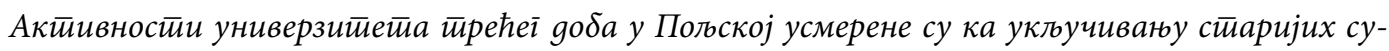

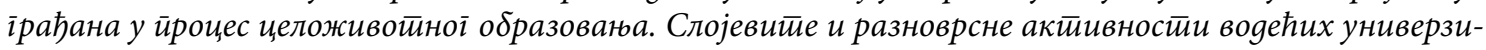

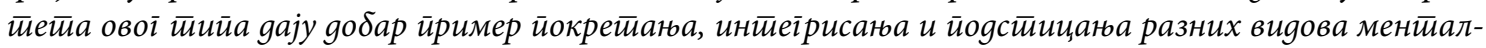

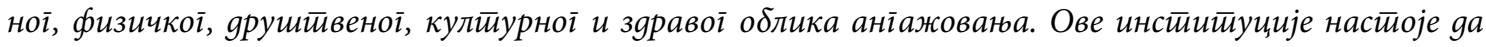

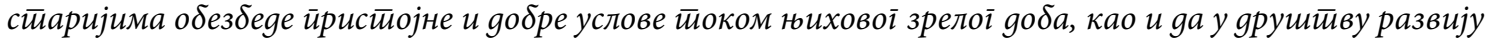
йозиичивну слику о іенерацији 50+. 